\title{
Living the imitatio: \\ The Heroic as Royal Paradigm in Ancient Macedonia
}

\author{
Hallie M. Franks
}

Over the course of the Classical period, the Argead kings of Macedonia promoted their dynasty's heroic lineage, the origins of which they traced to the great panhellenic hero Herakles. By the mid-4th century B.C., Philip II and Alexander III, the Great, expanded on this practice by implying or explicitly claiming their heroic (or even divine) status. On the day of his death, for example, a statue of Philip was carried in procession and enthroned in the theater at Aegae alongside the twelve Olympian gods. ${ }^{1}$ For his part, Alexander fostered a connection that verged on rivalry not only with Herakles, but also with Achilles and Dionysus-all of whom had achieved great conquests away from home. ${ }^{2}$ At Siwah, which Herakles also reportedly visited, the Oracle of Zeus Ammon acknowledged Alexander as the god's son, ${ }^{3}$ and Alexander seems to have promoted this status. ${ }^{4}$ Apelles painted a portrait of Alexander as keraunophoros, bearer of the thunderbolt, for the Temple of Artemis at Ephesos, creating, in the words of A. Stewart, "an unforgettable image of the prepotent universal king (basileus) calqued on that of the king of the heavens, Zeus Basileus." 5

While literary sources are concerned with these exceptional men and their claims, material remains offer vital evidence for a tradition of the royal self-image as it existed and was represented within the kingdom of Macedonia, and they offer

Diodorus Siculus, Bibliotheca historica 16, 92, 5. 95, 1.

2 See, for example, Curtius Rufus, Historiae Alexandri Magni 8, 10, 1; Plutarch, Alexander 15, 4-5; Arrian, Anabasis 7, 14, 4; Diodorus Siculus, Bibliotheca historica 17, 97, 3.

3 Strabon, Geographika 17, 1, 43; Diodorus Siculus, Bibliotheca historica 17, 51, 1; Curtius Rufus, Historiae Alexandri Magni 4, 7, 25-28; Plutarch, Alexander 27, 3-6.

4 This is suggested by Kleitos' mocking of Alexander as 'god-born' (ek theōn) in Plutarch, Alexander 50, 6.

5 A. Stewart, Faces of Power. Alexander's Image and Hellenistic Politics, Berkeley 1993, p. 196, cf. pp. 191-201 on the Alexander Keraunophoros painting. Cf. Plutarch, Moralia, De Alexandri fortuna 335A. The question of Philip's and Alexander's relationship with their own potential divinity has been discussed extensively, but space prevents a review of the bibliography here. For recent discussions, with a review of relevant ancient and modern sources see, for Philip, I. Worthington, Philip II of Macedonia, New Haven 2008, pp. 200-201; R. Lane Fox, Philip of Macedon: Accession, Ambitions, and Self-Presentation, in: R. Lane Fox (Ed.), Brill's Companion to Ancient Macedon. Studies in the Archaeology and History of Macedon, 650 BC - 300 AD, Leiden 2011, pp. 335-366, here pp. 362-365; for Alexander, Stewart, Faces of Power, pp. 78-85. 95-102; E. Fredricksmeyer, Alexander's Religion and Divinity, in: J. Roisman (Ed.), Brill's Companion to Alexander the Great, Leiden 2003, pp. 253-278, here pp. 270-278; E. Anson, Alexander the Great: Themes and Issues, London 2013, pp. 83-120. 


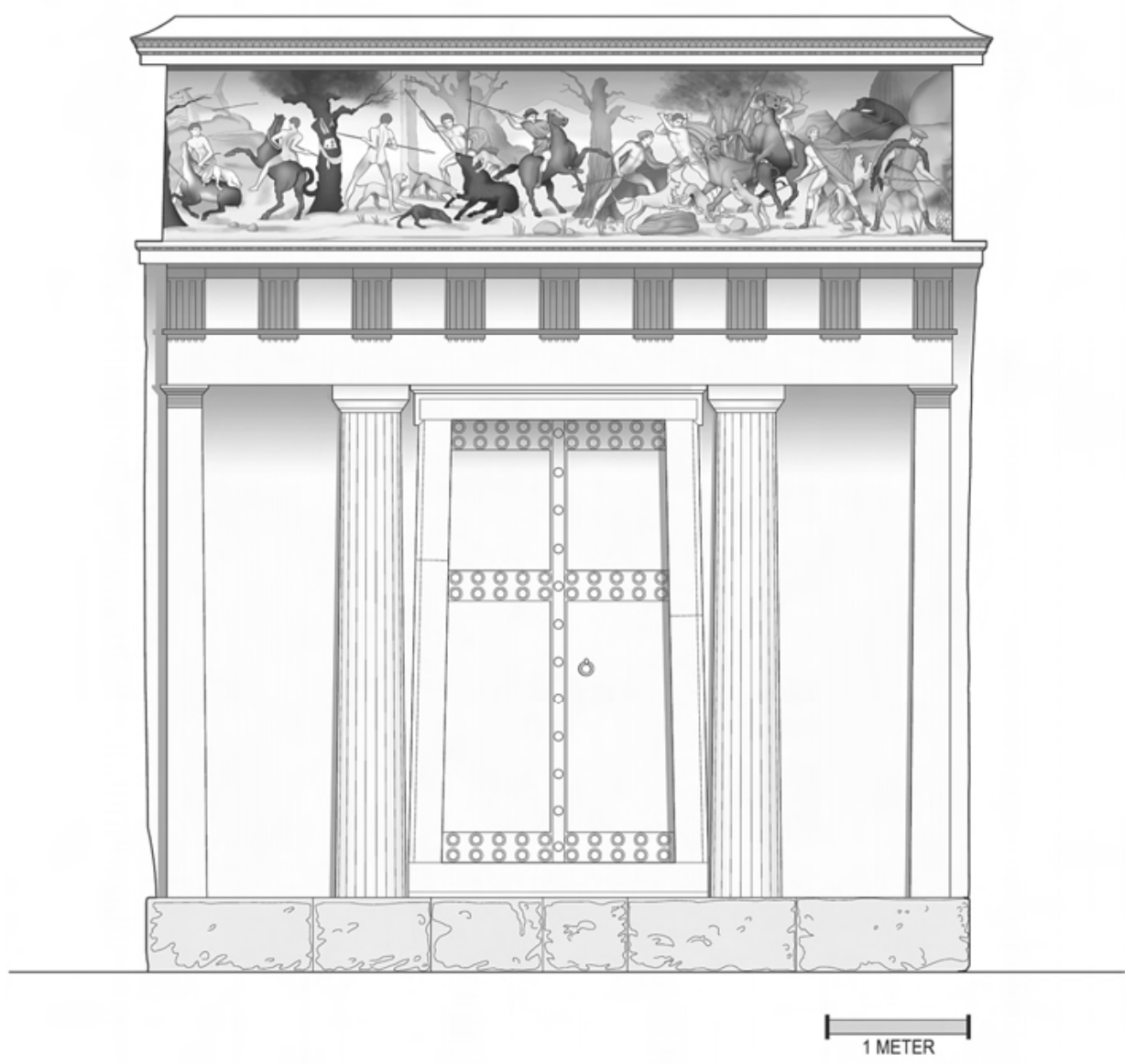

Fig. 1

Artist's rendering of Vergina Tomb II façade

ways of thinking about the questions with which this collection of essays is concerned. What was the context for the Argead claim to heroic ancestry, and what significance did this claim have in the kingdom? How, more specifically, did Macedonian royalty conceive of and represent its relationship with the heroic world?

To pursue these questions, I take as my subject a painted hunting scene, the crowning feature of a monumental Macedonian tomb known as Tomb II, located at Vergina, the site of the ancient city of Aegae (Fig. 1). ${ }^{6}$ Given the size of Tomb II,

6 This essay draws from my previous work on the frieze: H. Franks, Hunters, Heroes, Kings: The Frieze of Tomb II at Vergina, Princeton 2012. For discussion of the frieze, the tomb's excavation history, its contents and location, see ibid., pp. 4-19; see also C. Saatsoglou-

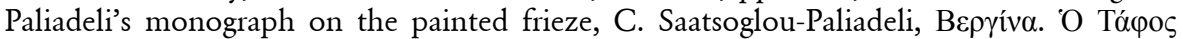

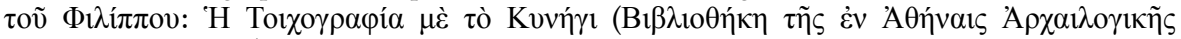

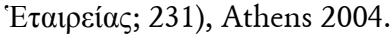


the opulent burial goods included within, its position under a monumental tumulus mound, and its location at Aegae, the kingdom's ancient capital city, I will proceed with the understanding that Tomb II is a monument commissioned for a member of the Macedonian royal family. Positioned above the entrance to the tomb, the painted frieze would have been highly visible during the public event of the royal funeral. It features ten men, who pursue a variety of wild beasts. While literary texts are read from left to right, this visual text begins, so to speak, in the center, the point on the vertical axis of the façade that is emphasized by the seam of the tomb's doors. Here in this central position, the place to which the viewer's eye is, in fact, directed, is a young hunter on horseback. This central hunter wears a purple tunic, and he is crowned with a wreath, a feature that sets him apart from every other hunter in the scene. Although somewhat isolated in his central position, this young hunter is in fact part of the activity that takes place to the right. He points his spear in that direction, toward a lion, which is surrounded by three additional hunters, including a second hunter on horseback. Like the central hunter, the horseman at the right is clothed in a purple tunic, and he, too, is given prominent placement; he is raised not only above the lion, but also higher than any other figure in the composition. Although he does not wear a wreath, he is distinguished in another way: he alone in the scene is bearded, a sign that he is not a young man, but a mature male.

These two horsemen, the bearded hunter and the wreathed central figure, are carefully distinguished from their companions: they hunt from horseback, they are clothed in purple, and they are given privileged formal placement. These details signal that these men are the protagonists, the main figures, of the scene. Despite their clear importance overall, it is unclear which of the four men involved will strike the blow that kills the lion. Neither of the horsemen is clearly picked out as the successful hunter.

The lion hunt is just one of four hunts that take place in the scene. Further to the right of the bearded horseman, a cloaked man prepares to spear a bear, which lies in the rock face at the right end of the panel. Below, a figure in a tunic and a shaggy cloak holds a net, perhaps to corral or weed out game for the hunters. To the left of the central hunter, two nude youths finish off a collapsing boar with the help of their dogs. Further to the left is a deer hunt, also in its final moments.

Manolis Andronikos' discovery of Tomb II in 1977 inaugurated a heated controversy over the identity of the occupant that continues to this day. The debate has centered around two proposals for the identification of the male in the tomb: The first, proposed by Andronikos almost immediately after the tomb's discovery, is that the tomb belongs to Philip II and that it dates to the year of Philip's death, 336 B.C. ${ }^{7}$ The second proposal is that it belongs to Philip III Arrhidaios, the half-brother of Alexander, who was assassinated in Macedonia in

7 M. Andronikos, Vergina: The Royal Tombs in the Great Tumulus, in: Athens Annals of Archaeology 10, 1977, pp. 1-72, here pp. 70-72. 
317 and buried some months later, in 316. I have discussed my own position on the date elsewhere, and so will not go into detail about it here, but this debate has had implications for our painting, since interpretations of the hunting scene have been brought to bear on the dispute over the tomb's occupant. ${ }^{8}$ Scholars have frequently associated the scene with a specific historical moment, and have even identified in the painting's protagonists portraits of historical figures: at different times, scholars have identified the two horseman as Alexander, Philip II, Philip III Arridaios, Alexander IV, and Kassander. ${ }^{9}$ The very variety of these proposals-a variety that exists even among scholars who agree on the point of the date-should caution us as to their reliability.

These attempts to link this hunting scene to a specific historical moment have limited our understanding of the image in two ways. First, the identification of the image as a representation of a historical episode has confined the interpretation to certain kinds of events described in historical sources. Second, the situation of the creation of the painting within a highly particularized historical moment (either in 336 or 316) has attached to the image meanings that are based on details of the politics, motivations, and personalities of that specific context. Meanwhile, the influence of existing traditions that would have been recognizable and meaningful to the Macedonian viewers of the painting is too often overlooked.

Given the function of the funerary monument as a memorial to an individual, I do think it is likely that historical individuals are inserted into the painting as the protagonists. But I am not interested in naming these men. Rather, in contrast to readings of the frieze in which the event is meaningful because well-known historical individuals participate in it, it is my contention that the protagonists take on meaning through their participation as horsemen in this hunt. This happens within their contemporary context, via paradigms that emerge out of longstanding visual and cultural traditions that are discernable in Macedonia and in the Hellenic world more broadly. Through these paradigms, the protagonist hunters are not only identified as members of Macedonian royalty, but are also positioned in relationship to heroic and dynastic histories and values, which, the image claims, they uphold. Read in this way, the hunting scene may be understood as an instance of visual communication that would be read by a broad Ma-

8 See my discussion of the date, with relevant bibliography, in Franks, Hunters, Heroes, Kings (footnote 6), pp. 116-126.

9 See, for example, M. Andronikos, Vergina: The Royal Tombs and the Ancient City, Athens 1984, pp. 115-116; L. E. Baumer / U. Weber, Zum Fries des ,Philippgrabes‘ von Vergina, in: Hefte des Archäologischen Seminars der Universität Bern 14, 1991, pp. 27-41, here pp. 38-41; E. Badian, A Note on the 'Alexander Mosaic,' in: F. B. Titchener / R. F. Moorton (Ed.), The Eye Expanded. Life and the Arts in Greco-Roman Antiquity, Berkeley 1999, pp. 75-92, here pp. 87-88; O. Palagia, Hephaestion's Pyre and the Royal Hunt of Alexander, in: A. B. Bosworth / E. J. Baynham (Ed.), Alexander the Great in Fact and Fiction,

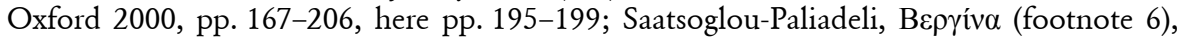
pp. 144-149. 
cedonian audience through its appeal to both an established conception of Macedonian royalty and an established way of representing that conception visually.

In addition to expanding the focus from the particulars of historical moments and historical personalities, this approach supplies a particular type of case study for the imitatio heroica. It is not the specifics of a particular hero-his deeds, identity, or attributes-that are the subject of this imitatio. Rather, the contemporary figures adhere to paradigms grounded in heroic or ancient royal behavior more broadly. The line that we draw between myth and the historical was not a clear one in ancient Greek thought, and in the case of royal Macedonia, this particular point is an essential one to understand. The Macedonian dynastic past includes the inherited past of the kingdom's 'historical' rulers, but also extends, through them, into its legendary founders, and, from there, into the world of their heroic predecessors. Dynastic lineage, therefore, both connects contemporary figures to the heroic world and reinforces paradigmatic performance through repetition. In other words, an appeal to the paradigm positions a contemporary figure in relationship not only to a distant heroic world, but also to a series of royal ancestors that preceded him in successfully fulfilling that paradigm.

With that foundation laid, I would like to turn to two aspects of the Vergina frieze that I believe evoke these paradigms, namely, the lion hunt from horseback and the hunt as a group.

On his campaigns, Alexander hunted in the royal Persian hunting parks, called, in the Greek sources, paradeisoi. While he hunted a variety of animals, Alexander's lion hunts are his most famous, and they seem to have inspired the prominence of lion hunts in both the royal practice and iconography of the Hellenistic period. ${ }^{10}$ These stories have fueled interpretations of the Tomb II frieze as an episode that reflects Achaemenid royal practices as they were adopted by Alexander during his campaigns, since lion hunts are uncommon in Classical Greek sources. But the appearance of the lion hunt in a Macedonian setting need not be the result of Alexander's Persian conquests or a representation of them. When we turn to the extant visual material in Macedonia, in fact, we find evidence for a tradition that includes the hunting of the lion from horseback-and this is a tradition in place prior to the lifetime of Alexander. This evidence exists primarily in coinage.

The first Macedonian king to mint coins in his name was Alexander I. The obverse of these coins features a mounted figure, clothed in a tunic and carrying two spears. This image continues in some form through Alexander I's reign and on the coinage of his successors, throughout the fifth century and into the fourth; a horseman is prominent even on the coins of Philip II. The appearance of the horseman on the kingdom's coinage intimately links this figure to the Macedonian king, whose name appears on the reverse as the authority under which the

10 Plinius, Historia Naturalis 35, 138; Polybius, Historiai 22, 3, 9; Athenaeus, Deipnosophistae 5, 102 b-c; Plutarch, Demetrius 50, 6. 

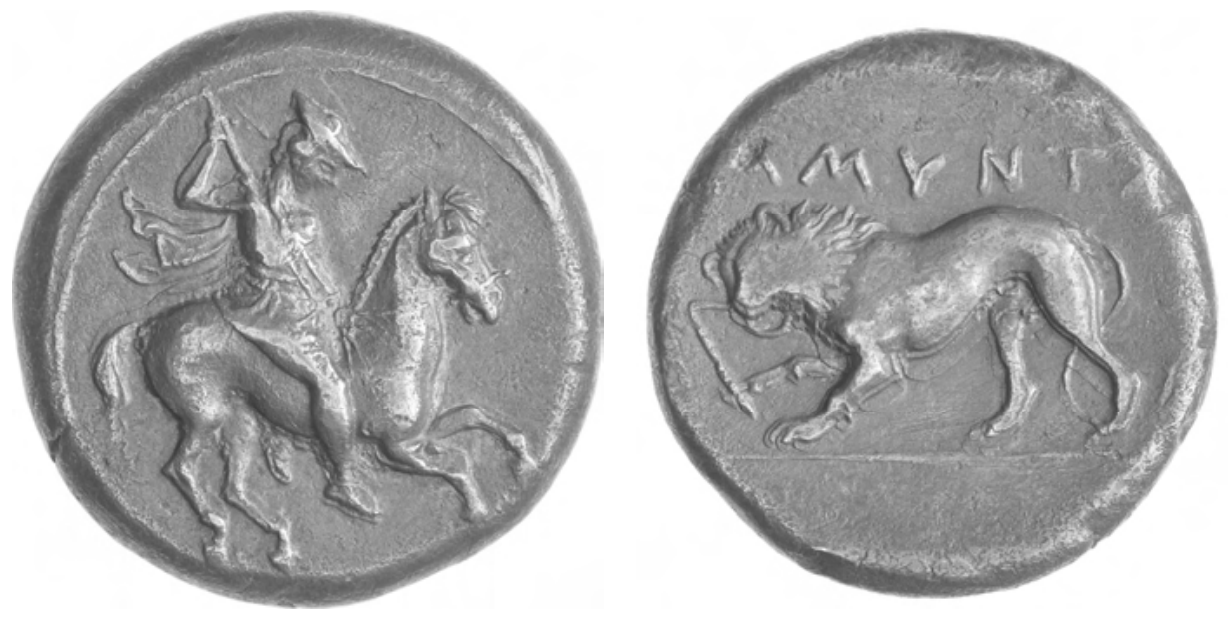

Fig. 2

Horseman (left) and lion (right) with legend AMYNTA, silver stater of Amyntas III, 393/92-370/69 B.C., New York, American Numismatic Society 1944.100.12168

coin was issued. Carmen Arnold-Biucchi has argued that the horseman offers a "general representation of 'the King."'11 Like the figure that appears on the Persian darics, which shows the Great King as hunter-protector, crowned and running forward with a bow and arrows in hand, the figure here is not a portrait of the individual in office, but, more accurately, a portrait of the political body of kingship. ${ }^{12}$ Whether interpreted as a hunter or a warrior (which he should be is unclear), the image suggests the horseman's expertise in handling the weaponry with which he is armed and the horse on which he rides, and, as a result, he possesses the bravery to confront a dangerous foe or prey. In this way, the horseman might be considered as an emblem-a visual paradigm-of Macedonian royalty. With each successive generation of use throughout the fifth and fourth centuries, the antiquity and visual legacy of this image accrues, lending the paradigm of the horseman increasing historical authority as a symbol of Macedonian kingship.

On certain denominations, this mounted figure is paired with a lion on the reverse. At first there is no real indication that the obverse and reverse should be connected, but this changes in the fourth century under the king Amyntas III, the father of Philip II, who ruled Macedonia from the late-390s to around 370. On the coins of Amyntas, the horseman and lion are still shown on their respective sides, but here, as William Greenwalt has convincingly argued, the two sides come together into a single narrative scene that wraps around the coin (Fig. 2). ${ }^{13}$ In this-a

11 C. Arnold-Biucchi, Alexander's Coins and Alexander's Image, Cambridge, Mass. 2006, p. 28.

12 See Franks, Hunters, Heroes, Kings (footnote 6), pp. 41-57.

13 W. Greenwalt, The Iconographical Significance of Amyntas III's Mounted Hunter Stater, in: Ancient Macedonia 5, 1993, pp. 509-519, here pp. 510-511. 
true hunting scene-the horseman raises his spear in his right hand and directs it downward. On the reverse, under the name "AMYNTA" is his prey, a lion, which gnaws on a broken spear shaft. The horseman on earlier Macedonian coinage carried two spears; in this case, he has thrown one, and although he missed the lion, the spent spear distracts the beast and allows the hunter a second strike. This remarkable scene suggests that the horseman on earlier coinage may have been a hunter, but more significant here is that Amyntas' staters specifically link the imagery of the lion hunt, performed from horseback, to the Macedonian king, the authority that issued the coin.

The image of the lion hunter on horseback brings us back to the Tomb II frieze. I would situate the protagonists of the hunting scene within this long, public visual tradition of the horseman. The act of hunting from horseback connects these men to the existing, royal paradigm, visually expressed by the horseman on coinage. This appeal to a local tradition of representing royalty calls into question the claim that Alexander's hunts in Persia were a necessary model for this scene, but it also, and more importantly, highlights the deep connections that might be drawn between the kingdom's pasts and its political present. If the protagonists (the central horseman and the bearded horseman) are meant to represent historical personages, their appearance according to the paradigm of the horseman implies, I believe, their possession of qualities desirable in a Macedonian king. Further, it insinuates their position within the long dynasty of Macedonian kings, who appealed to and filled the ideal of the horseman before them. This is not quite, yet, an imitatio hero$i c a$, but it underlines the point that the past-whether, strictly, dynastic or heroicprovided a crucial model through which successive rulers defined the qualities of the Macedonian king.

The horseman is the first of the two paradigms that I propose are operating in the Tomb II frieze; the second is the hunt as a group, an activity that has meaningful parallels in the Greek heroic tradition. Nancy Felson Rubin and William Merritt Sale have identified certain epic episodes as part of a tradition that they call the hunting-maturation myth. ${ }^{14}$ This tradition casts the group hunt as an initiatory episode in the lives of young heroes. There are two prominent examples of this kind of myth: one is a hunt on Mount Parnassus, attended by a young Odysseus, and the other is the hunt of the Calydonian boar by Meleager.

In the Odyssean version, the young hero joins the home of his mother's father, and participates in a boar hunt alongside his maternal uncle and cousins. ${ }^{15}$ Odysseus kills the boar, offers the spoils to his grandfather and uncles, and returns to his parents, having successfully completed the hunt, and, thus, his initiation. ${ }^{16}$ It is

14 N. F. Rubin / W. M. Sale, Meleager and Odysseus: A Structural and Cultural Study of the Greek Hunting-Maturation Myth, in: Arethusa 16, 1983, pp. 137-171; see further discussion in Franks, Hunters, Heroes, Kings (footnote 6), pp. 67-72.

15 Homer, Odyssey 19, 395.

16 Ebd. 19, 428-466. 
after this hunt that he successfully courts and marries Penelope. Like Odysseus, Meleager joins the men of his mother's family in the hunt, this time for the Calydonian boar, which Meleager kills. ${ }^{17}$ At this point, however, Meleager's hunt fails: he gives the spoils away, not to his family, but to his beloved, Atalanta. This gesture offends both Artemis, the goddess of the hunt, and his uncles, whom he kills in the quarrel over the boar's hide.

When successful, as in Odysseus' case, the result of this initiatory hunt is the incorporation of the youth into the world of mature men. But when it fails, as in the tale of Meleager, this kind of hunt has the potential to disrupt and even destroy a family. Despite the very different outcomes of these episodes-Odysseus' success and Meleager's failure-they adhere to similar narrative structures, and consist of certain key components: (1) the young hero accompanies the male members of his mother's family on a hunt in the wild; (2) during the hunt, the youth confronts the prey directly, and he succeeds in killing it; (3) in the successful version of the event, the young hero returns home with his spoils, where he is received as a, now, mature and full member of the family. These episodes reflect, therefore, a particular type of heroic hunt, recognized by adherence to this structure and by the inclusion of these particular elements.

Later sources, outside of the mythological tradition, also incorporate this kind of hunt; one is included in the "Cyropaedeia," Xenophon's fictionalized biography of Cyrus the Great, written in the early fourth century B.C. The heroic hunting-maturation motif is incorporated in Cyrus' biography as part of the young king's education, and we can recognize, in one of his hunts, its key components. (1) Cyrus spends his youth at the court of his maternal grandfather, Astyages, where he accompanies the mature males of this family on a hunt in the wild. ${ }^{18}$ (2) On this hunt, Cyrus single-handedly kills a boar and a deer. ${ }^{19}$ (3) He returns home with the spoils, which he offers to his grandfather, and he is received as a full and mature member of the family, as in the successful Odyssean version of the hunt.

While Cyrus' hunt is only a small part of his biography, it has lasting effects. Cyrus continues to value the hunt, and it is, in part, this love of exercise and competition that sustains the king's moral virtue and his good character, which are at the core of Xenophon's ideal. In this way, through the inclusion of this type of hunt, Xenophon subtly elevates his Cyrus, endowing him with a specific kind of history (the successful version) that he shares with Greek heroes. He participates, in other words, in an imitatio heroica that is based not on a direct comparison to Odysseus or Meleager, but, instead, on his successful participation in a specific event in which heroes also participated.

17 Homer, Iliad 9, 543; Apollodorus, Bibliotheca 1, 8, 2; Diodorus Siculus, Bibliotheca historica 4, 34; Ovid, Metamorphoses 8, 414-424.

18 Xenophon, Cyrupaedia 1, 4, 5-6.

19 Ebd. 1, 4, 7-8. 
These literary hunts offer a second paradigm through which, I propose, we might also view the group hunt of the Vergina frieze. Like the initiatory hunts of Odysseus and Cyrus, our image features a group of men, from among which one youth (the central, wreathed horseman) is singled out as particularly important. In addition, he turns towards the lion after having decisively struck the boar, providing some overlap in the literary focus on the boar as the central prey. Also singled out in our painting is the bearded horseman, who, I would posit, represents the mature world into which the wreathed hunter is to be introduced.

Not only are the 'characters' of this kind of hunt present in the image, but the moment represented is also telling. As is the case with the epic hunts, the visual scene does not focus exclusively on the glory of the single-handed kill; it depicts, instead, the point at which every member of the group has an opportunity to slay the beast. The Vergina frieze shares this feature not only with the literary sources, but also with images of Meleager's hunt, which survive in Greek vase painting. In these images, Meleager himself is never obviously distinguished from the group as the successful hunter. ${ }^{20}$ Instead, at the moment depicted, everyone appears to have the opportunity to strike the prey. This choice of moment in which the hunters appear as a coherent group underscores, I believe, the social world of mature men to which success in this kind of hunt can-and, ideally, will-lead.

I read the Vergina frieze as I read Cyrus' hunt. It is an imitatio heroica not in the sense that it represents or reenacts one of the hunts recorded in epic, but in that it offers a fourth-century conceptualization of this special type of event, connected to the heroic hunting-maturation myths through structure and result. As in Cyrus' biography, this kind of event indicates that the life of the protagonist-for Tomb II, that of the central hunter-is punctuated by the same events that define the lives of epic heroes.

The adherence to paradigms grounded in the royal and heroic pasts is not incompatible with what we know about the self-presentation of Macedonian royalty. Although evidence for royal customs before the reign of Alexander is thin, there are hints that the past was a vital component of the self-representation of the kingdom's elite throughout the Classical period. One aspect of this was the Argead claim of descent from the panhellenic hero Herakles, whose descendants came north from the Peloponnese to found the royal house of Macedon-a claim made at least as early as the reign of Alexander I. ${ }^{21}$ Herakles, therefore, is a figure in which these two pasts, heroic and royal, intersect and from which Argead authority ultimately issues.

The funerary context under discussion here offers an additional way in which Homeric models were present in contemporary practice. In epic, dead heroes like Patroklos and Hektor were burned on pyres. On the pyre of Patroklos, Achilles

20 See, for example, a red-figure pelike from Benghazi (ca. 370 B.C.): St. Petersburg, The State Hermitage Museum, Inv. No. B-4528.

21 Herodotus, Historiai 8, 137. 
sacrificed horses, and the ashes of Hektor were collected in a golden urn, and covered with a purple cloth. ${ }^{22}$ At Vergina, there seem to be strong allusions to these practices. In connection with Tomb II, Andronikos uncovered evidence of a funeral pyre, among the debris of which were found metal horse trappings. ${ }^{23}$ Further, the deceased's remains were treated like Hektor's, wrapped in a purple cloth and placed in a precious metal vessel $;{ }^{24}$ in Vergina's Tomb III, as well, the burned bones of the young deceased were covered in a purple cloth and placed in a silver hydria. ${ }^{25}$ All of these features-pyres, horse sacrifices, and the treatment of the deceased's ashes by wrapping them in purple cloth and depositing them for burial in a precious metal vessel-are distinct parts of heroic burials, and each is also attested in the royal graves at Aegae.

The modeling of the Tomb II hunting scene on a paradigm offered by the heroic world is, therefore, one example of a larger cultural tradition that incorporates the heroic both in practice and in representation. But the Vergina frieze offers a particularly sophisticated nesting of visual archetypes. Embodying the emblem of the horseman, the protagonists of the Vergina frieze are shown as worthy inheritors of a local legacy: the ancestral office of (Argead) kingship and the distinguished history of men who filled it. The origin of this dynasty in the heroic world is underscored by the second paradigm of the hunt. Through their adherence to the structure of the epic maturation-hunt, the fourth-century horseman is likened to the heroes that usually participate in this kind of event. While they might have distinct origins that influence their appearance in the visual tradition, the horseman and group hunt contribute to the same end in the Vergina frieze. The contemporary subject is positioned as both the beneficiary and fulfillment of a particular lineage that connects his immediate glory, the recent dynastic past, and an ancient, heroic past. Our hunters do not become heroes themselves, but the imitatio-of both the heroic and the more recent-serves as an effective way of defining exceptional individuals in the present.

With this interpretation, we are a long way from the simple depiction of a historical moment. I should acknowledge that my interpretation implies a deep concern with dynastic succession, and that this is something that has been raised repeatedly as a motivation behind the patronage of the painting. It is frequently assumed that the successor to the deceased inserted himself into the painting as a bid for his own kingship, but it might instead be the case that the painting represents the relationship between the deceased in the center and his predecessor, underscoring his proper place-now solidified by his death-in a more deeply conceived dynastic legacy, looking not forward, but back, and extending to the very origins of the Argead dynasty in the heroic world.

22 Homer, Iliad 23, 160-171. 240-245 for Patroklos. 24, 795 for Hektor.

23 Andronikos, Royal Tombs and the Ancient City (footnote 9), pp. 69. 97-98.

24 Ibid., pp. 168-171.

25 Ibid., pp. 198-217. 
In conclusion, the dynastic and heroic pasts serve as models for behavior, as well as a means through which a historical king's nature and his place within a certain lineage are realized. The recognition of references to such pasts through visual paradigms allows us to move away from the restrictive parameters of the historical (or, even, the idealized historical) and provides a new background against which we might consider the frieze as one example of a royal image, constructed around local conceptions of who the Macedonian king is, what his relationship to previous kings and to the heroic world should be, and how this particular imitatio heroica may be expressed visually.

\section{Acknowledgements}

Fig. 1 Daniel Lamp, in: H. Franks, Hunters, Heroes, Kings: The Frieze of Tomb II at Vergina, Princeton 2012, p. 6, Figure 3. Reproduction courtesy of the Trustees of the American School of Classical Studies at Athens.

Fig. 2 Photo courtesy of the American Numismatic Society. 
